\title{
SURVEY OF PROBLEMS IN FISHERY
}

\section{ADMINISTRATION}

\author{
Karl F. Lagler \\ University of Michigan \\ Ann Arbor, Michigan
}

IN ORDER to obtain a concept of the kinds and relative magnitudes of the problems which vex Iishery administrators, a questionnalre was sent to some 60 such officials in this country and Canada. The perlod involved was February through April, 1949. Th1rty-elght replies were received, including 30 from varlous States, 2 from Canadian Provinces, 1 from the Territory of Hawail, and 3 from the U. S. Fish and Wildilfe Service.

This report includes a condensed version of the questionnaire and a summary of the replies.

\section{DIGEST OF ANNOTATIONS ON THE VARTOUS QUESTIONS}

Efflclency of organization is considered a minor problem. Only one state recognizes a major fault in the structure of its organization: "the placement of responsibility is neither clear nor definite." As for paperwork, three units of the Fish and Wildlife Service and more than half the State agencles questioned mention considerable "red tape," but this is always termed a necessary evil. One State actually needs more reports in order

This survey was a class project in a graduate-student seminar on this subject under the direction of Professor Lagler at the University of Michigan.

Miss Virginia Field and Mr. Max Proffit, with Professor Lagler, complled most of this report from brief digests prepared by other members of the seminar to show the status of various problems.--The EDITORS. to be "fully aware of the efficlency of each of the hatcheries."

Well-trained personnel is hard to obtain and to hold, according to 60 percent of the replies. This situation is generally due to lack of funds, but in at least four organizations the method of hiring and firing is partly responsible.

Politics is a complex and important problem in most states. Personnel, funds, and policles are controlled, one way or another, by State governments; and there is evidently a difference of opinton among fishery administrators concerning the ideal relationship. Some of the comments, roughly separable into four categorles, are interesting and varied:

--Politics and Personnel--

"Uncertainty of tenure does not invite top-qualified men."

"No merit system" of employment and promotion.

--Politics and Policies--

"Due to our county unit system the leglslatures have a large volce in our operation in each county."

"Each succeeding legislature sees adverse legislation introduced by specialinterest groups. Results are gory."

"Politics are always a threat to long range programs and overall efficlency of operation."

"Political expediency and conservation requirements often conflict."

--Politics and Funds--

The organization is "hampered politically only by difficulty of getting appropriations."

"Some political influence is felt as it concerns funds or programs." 
CONDENSED QUESTIONNAIRE ON PROBLEMS IN FISHERY ADMINISTRATION AND

SUMMARY OF REPLIES ${ }^{1 /}$

\begin{tabular}{cc}
\hline Problem & Status of Problem : Fallure \\
Major Minor None $:$ to check \\
(...Percent of Replies....)
\end{tabular}

Eficiency of Organization

(including red tape)

$10-58$

8

Personnē

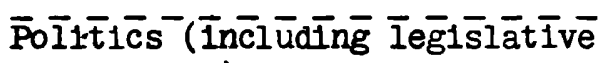

relations)

$\overline{\text { Fund }} \overline{\mathrm{s}}$

$----1---1--1$

$\overline{40}--\frac{4 \overline{2}}{13}-$

Law Enfōorcement and the changing of Laws 26 44

20

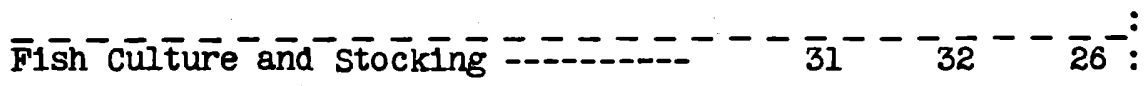

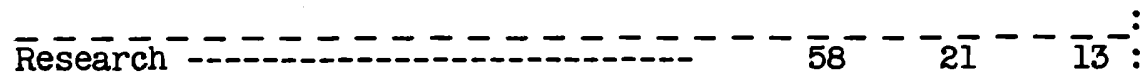

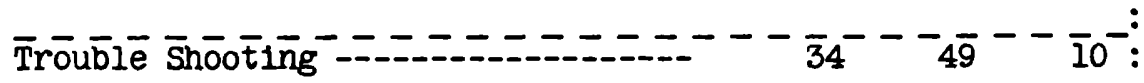

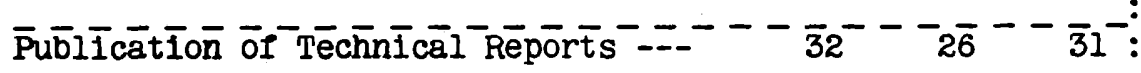

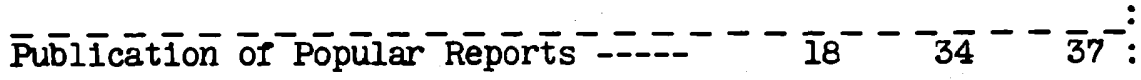

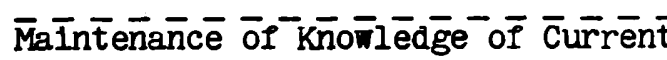

Status of the Fisherles -..-.-.--

41

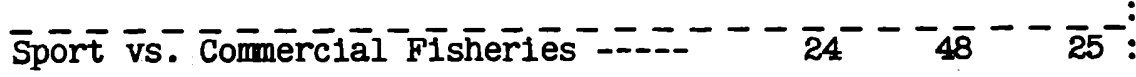

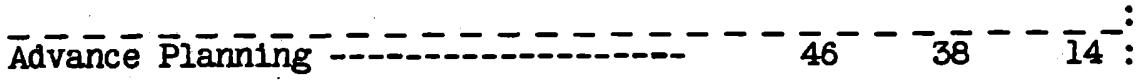

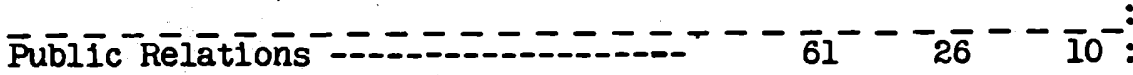

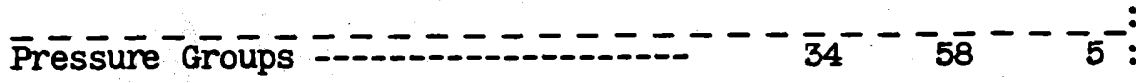

Cooperātion with other Á̄encīes, State or Federal, and Integration of Activities

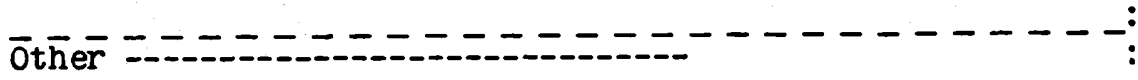

Please $\overline{\text { Indicate }}$ which of the above problems is greatest.

1/For each type of problem, the correspondent was asked to give a statement of its nature in his state or administrative unit and to check status. 
--Politics in General--

"B1-partisan commission makes problem of politics minor."

"Politics is a minor problem, even though the organization is under political control."

"This is a major problem, because the organization is controlled by politics."

"Polltics is no problem, but congressmen and senators st1ll cause a little trouble by referring their constituents' questions to us for reply." (In this case, the fire is apparently out and the ashes just need a little kicking and stomping.)

Sixty percent of the organizations are short of funds, and legislative control of appropriations is a frequent headache. The Fish and Wildlife Service units are chronic sufferers. Two organizations call funds adequate for justiflable projects but not for salaries. On the other hand, one organization goes on record as follows: "Proposed appropriations likely to strain present organization by imposing too rapid growth."

The 11shery administrator's greatest concern in connection with law enforcement and the changing of laws is their effect on the adoption and retention of scientifically sound management programs. For the most part, both laws and enforcement prove fairly satisfactory, and the problem is not too serious. The exceptions to this are contained in the following quotations:

"Too much politics; awful enforcement; could write a book about this."

"Present warden force overworked."

"Laws change too frequently."

"Laws are not based on sound principles."

The greatest problem of agencies that favor intensive stocking is to meet the increased demand for legal-sized Iish, a demand brought about by increased 11shing pressure. Where curtallment of stocking is advocated, the problem is to convince the public of the soundness of the policy. In general, stocking and fish-cultural programs are hampered by pol1t1cs and outside pressure groups, insufficient funds, limited lacilities, and scarcity and high cost of fish food.

With reference to stumbling blocks in research, one-third of the organizations 1ndicated great need for additional funds and personnel. One agency stated that its long-range research programs are often endangered by outs1de attacks; another sald its sportsmen and legislature expect too much for too little. Several organizations support no research, hence have no problem.

Regarding trouble shooting, there is the problem of how much of this unscheduled work to do, and the problem of funds and personnel with which to do it. Add1tional allments are volced as follows:

"Trouble shooting is a major problem because demands are so unexpected and of ten upset previously formed plans."

"We usually learn of troubles after the time for action has passed."

Publication of technical reports is considered a minor or nonexistent problem in 80 percent of the organizations. In this group we have those who do not publish and feel no need to publish at present, those who publish little and need no speclal vehicles for their output, and those with prolific staffs and adequate facllities; this last condition is realized generally in those states that sponsor their own technical periodicals. In contrast, the Flsh and Wildlife Service administrators are unanimous in volcing a strong need for facllities and funds. The same need is reflected in the following comments from state agencles:

"... a major problem because sportsmen are generally not sold on the need for these reports."

"Backward--not enough and not comprehensive."

"A major bottleneck to programs in research."

The publication of popular reports is a problem which is rapidly nearing solution as more and more States 1ssue conservation magazines. In addition, increased use is being made of local newspapers. The States that make no provision for popular reports almost unanimously admit a serious 
handicap. One administrator (Fish and Wilallfe Service) enlarged on his particular problem, as follows:

"We prepare lew popular articles. Pollcy discourages our issuance of such works, since they can be construed as propaganda. One of our major faults exists in our inadequate public relations."

Maintenance of knowledge of current status of I1sheries is one of the "big Iour" problems, according to tallies of the questionnaire reports. Most of the comments may be packed into this brief statement: the organizations are small, and the fisheries vast. As usual, however, we have another viewpoint: "A minor problem easily met by establishment of field biology stations whose men can watch the changes in fisheries day by day."

Although there are many conflicts between sport and commerclal fishing interests across the country, the replies indicate that generally the conservation agencles are not deeply involved. Two exceptions to this are:

"We have trouble obtaining money for sport 11shery research, but not for commerclal projects."

"Rather a serious conflict; the survey does not administer to ilsheries, but we are concerned indirectly, for both sides come to us continually with their troubles. Also, we wish to be able to recomend administrative measures equitable to both fisheries."

Advance planning is one of the most troublesome problems facing the administrator. The most common reason is that appropriations are generally granted on a year-to-year basis, and plans must be made accordingly. Also, as brought out in the following comments, the administrator may be powerless for other reasons to formulate long-range plans.

"Cannot depart very far from wishes of sportsmen."

"We set up plans; then someone wants another type of work done."

"It is difficult to plan ahead because of unforeseen demands of trouble shooting."
"The department is suffering from growing pains. Rapid expansion of 11 sh production facilities has handicapped long range planning."

In public relations most of the States have a problem of first-rate 1mportance. Lack of funds and lack of personnel are the principal checks on effective publicrelations programs. The situation is summed up by one administrator:

"This is a problem of major importance because biologists usually sell their own programs, and there are not enough biologists to be both public relations men and research men."

Pressure groups are regarded as a nuisance by most administrators. Three agencles, however, reported no problems due to pressure groups; and three more actually considered their pressure groups beneflclal, saying:

"We recelve sound proposals at public hearings for these groups."

"We achieve excellent relations through these assoclations."

Pressure groups give "construct1ve help, usually."

Cooperation with other agencles, State or Federal, and integration of activities is no problem. According to the tone of the comments, all lish men are brothers under their scales. For example:

"Excellent cooperation."

"Complete harmony."

"Very good cooperation."

"Increasingly better."

Listed as other problems in 11shery management are "Iriction among personnel" and "how to find four extra hours in a twenty-four hour day."

Tabulation of the most important problem shows that money is the root of most, If not quite all, evil. In second place is public relations or education, the problem most important to a group of executives who contend logically that this is basic, the real key to all other problems of fishery administration. 